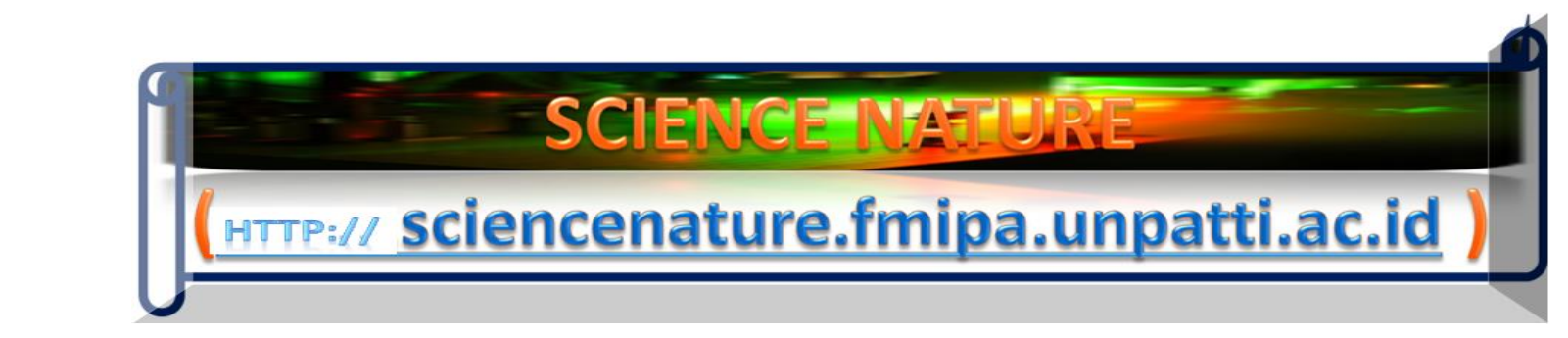

Science Nature 2(1), pp.066-070 (2019)

e-ISSN 2654-6264

DOI: https://doi.org/10.30598/SNVol2Iss1pp066-070year2019

\title{
The Discovery of NEW Golobe and Its Amazing Healing System
}

\author{
Hendry Izaac Elim (Elim Heaven $)^{1-7^{*}}$ \\ ${ }^{1}$ Specific Laboratory of Electronics and Instrumentation (ELINS lab), Physics Department, \\ Faculty of Mathematics and Natural Sciences (FMIPA), \\ Pattimura university, Indonesia 97233 \\ ${ }^{2}$ Nanomaterials for Photonics Nanotechnology Laboratory (N4PN Lab.), Department of \\ Physics, FMIPA, Pattimura University, \\ J1. Ir. M. Putuhena, Poka, Ambon, Indonesia 97233 \\ ${ }^{3}$ Nanotechnology Research Center and Innovative Creation (PPNRI-LEMLIT), Research \\ Center of Pattimura University, Pattimura University Campus, J1. Mr. CHR. Soplanit, \\ Rumah Tiga, Ambon, Indonesia 97234 \\ ${ }^{4}$ Multidisciplinary Research Center of Excellence (MrCE), \\ UNPATTI, Jl. Chr. Soplanit, RumahTiga, Ambon, Indonesia 97234 \\ Jl. Ir. MartinusPutuhena, Poka, Ambon, Indonesia 97233 \\ ${ }^{5}$ Maritime and Marine Science Center of Excellence (MMSCE) \\ Jl. Dr. Leimena, Ambon, Indonesia 97234 \\ ${ }^{6}$ Theoretical Physics Laboratory, Physics department, Pattimurauniversity, \\ Ambon, Indonesia 97233 \\ ${ }^{7}$ Development and Innovative Center (PPI) of Pattimura University, Indonesia
}

Received : February 27, 2019

Revised : March 3, 2019

Published : March 11, 2019

Copyright @ All rights are reserved by H.I. Elim (Elim Heaven)

Corresponding author: "Email: hendry.elim@staff.unpatti.ac.id 


\section{Abstract}

Here, one reported a discovery of new golobe or a novel kind of zingiberaceae fruit in a forest of Layeni village located in Teon-Nila-Serua (TNS) district of Seram island, Maluku province, Indonesia in the late afternoon on $25^{\text {th }}$ February 2019. The new golobe is very different from the four (4) formal types of golobe fruits studied before. After intense prompt investigations, the new golobe was named as Elim alliacea based on the taller tree and fruit hard skin structures as well as its unique taste. Furthermore, the healing system of the golobe was identified to be very excellence in handling toxic instantly. This discovery suggests a prominent potential of this fruit as multitasking healing herbal medicine for future complicated deceases on earth.

Keywords: Discovery, New Golobe, Layeni village, West Seram.

\section{LETTERS}

The sciences of natural products [1] are distinguished from human synthesis products due to its self-growing systems from cell to cell, or from DNA to RNA until the scale of molecular system up to bulk physics, and so forth. Furthermore, all the consistency contents of the natural products quality are stable in their original natural environment on earth and its beyond. Currently, the pharmaceutical industry in producing herbal medicine products has spent of over US\$ 60 billion worldwide [2]. This means that many people in the world have realized to leave healthy by hindering unpredictable side effects of chemical synthesis drugs. As the world is getting small due to the advancement of human engineering technology, many new inventions of natural products in an unexplored area, for example the new potato in Peru [3]. Moreover, by improving the understanding of the natural science in herbal medicines

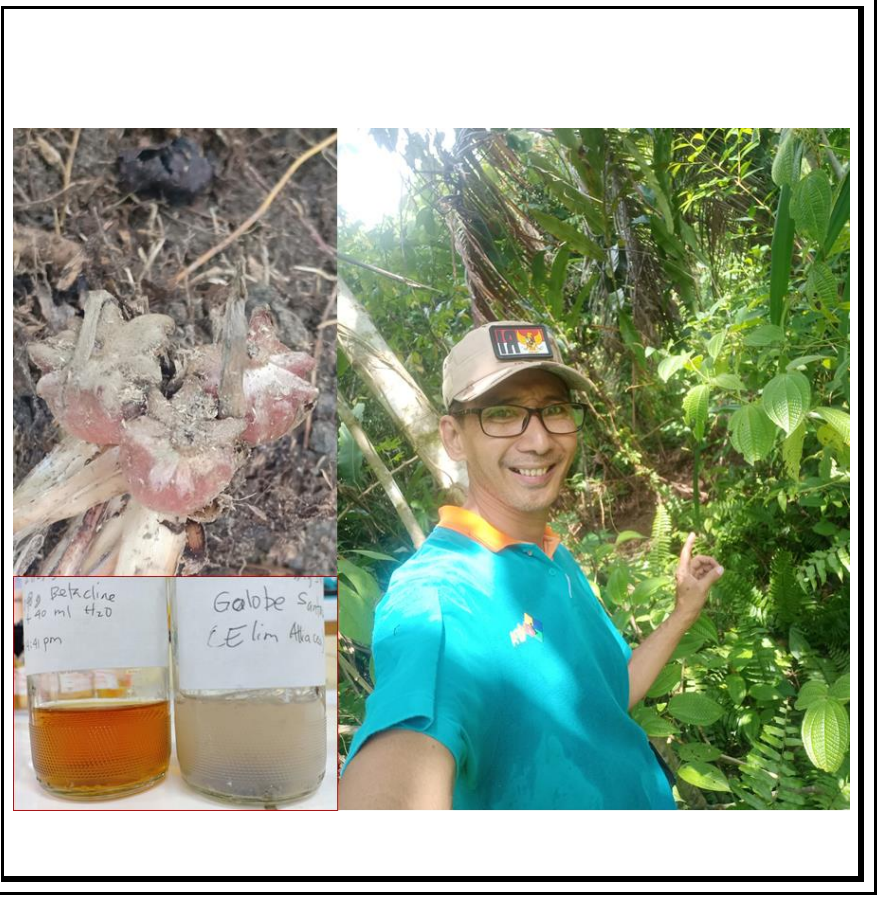

through both theoretical physics works [4-5], and an integrated experimental researches involving a variety spectroscopy measurement of nanostructure and size interactions, one could find out many unique behaviors and physical properties of such various structures and size of nanomaterials [6-9]. This idea had been proved by many different interdisciplinary scientists, for instance like the ones written by B. Alberts [10] of the breakthrough in 2011 about the application of HIV/ AIDS vaccines to thousands of volunteers and the Itokawa, Japan scientists mission to the space to get the sample of the asteroid.

In present letter, we report a discovery of new golobe (zingiberaceae fruit) in a small village of Layeni, Teon-Nila-Serua (TNS) district located in the largest island of Seram in Maluku province, Indonesia. Such golobe fruit called according to local people as galobe santan has a very different skin structure and taste from their former 4 types well-known fruits. Furthermore, the new golobe has been initially identified to strongly handle the toxic very well as reported in this work. 


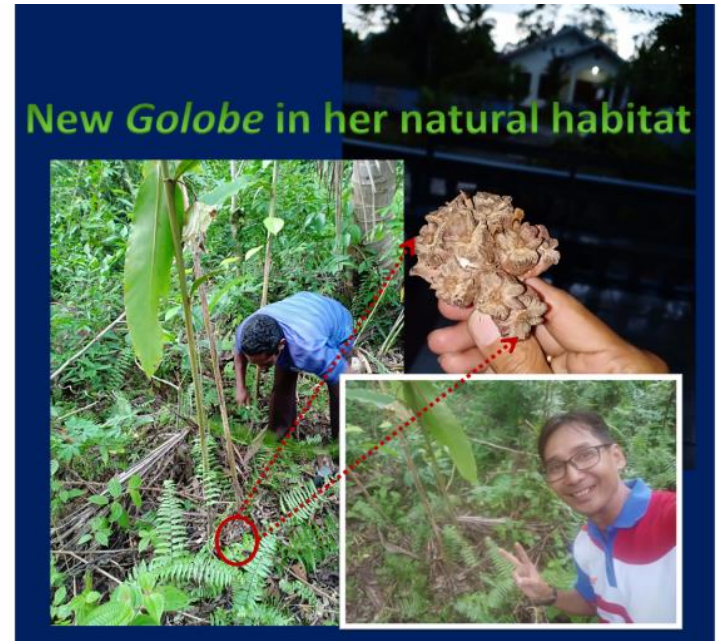

Figure 1. New golobe in her natural habitat of TNS district, Layeni village, West Seram, Malulu province, Indonesia.

In fact based on the search in the whole North Maluku and Maluku provinces consisted of 1340 islands mostly the small pretty islands with 5 big islands, there were at least 4 types of golobe : (1). Halmahera susu golobe (Hornstedtia alliacea) [11], (2). Halmahera golobe or Ambon golobe (Zingiberaceae alliacea), (3). Halmahera rambutan golobe (Amomum sp.), and (4). Ambon halia golobel Halmahera kelereng golobe (Etlinger alba (Blume) A.D. Poulsen) [12-16]. The natural environments of all such interesting fruits are in general in the areas of high moisture forests. Recently, these all types of golobe trees are very rare to find even in its original areas where they used to grow.

Figure 1 shows for the first time when one unpredictable discovered the new golobe with the help of the local people to obtain it in his forest on $25^{\text {th }}$ February 2019. The fruits were wildly grown among many different trees such as Calamus rotang, and coconuts, and many different types of bushes.

Figure 2 depicts a proposed new name of the new golobe as Elim alliacea after the location of the invented golobe trees were cleaned, and all the parts of the tree were promptly investigated, and identified, respectively.

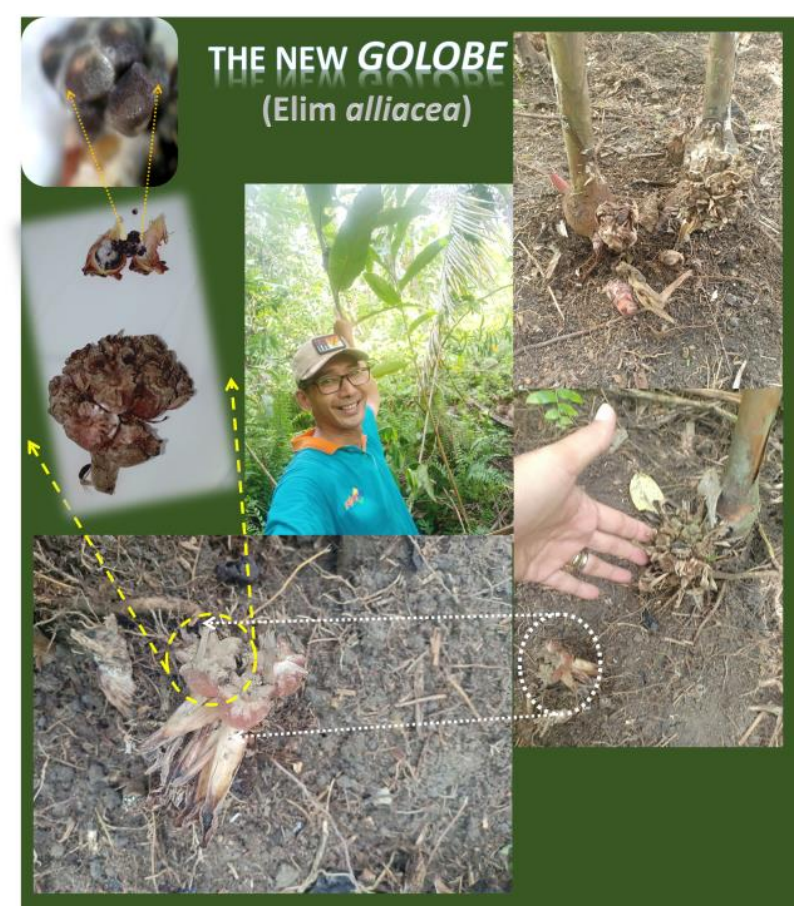

Figure 2. The nature of new golobe and her first discovery on $25^{\text {th }}$ February 2019 with her suggested name as Elim alliacea.

In Fig. 3, it is shown the physical comparison of the whole goloba fruits in order to simply see the obvious differences. While the physical fruit structures of Elim alliacea was identified from its outer skin to the inner of its seed.

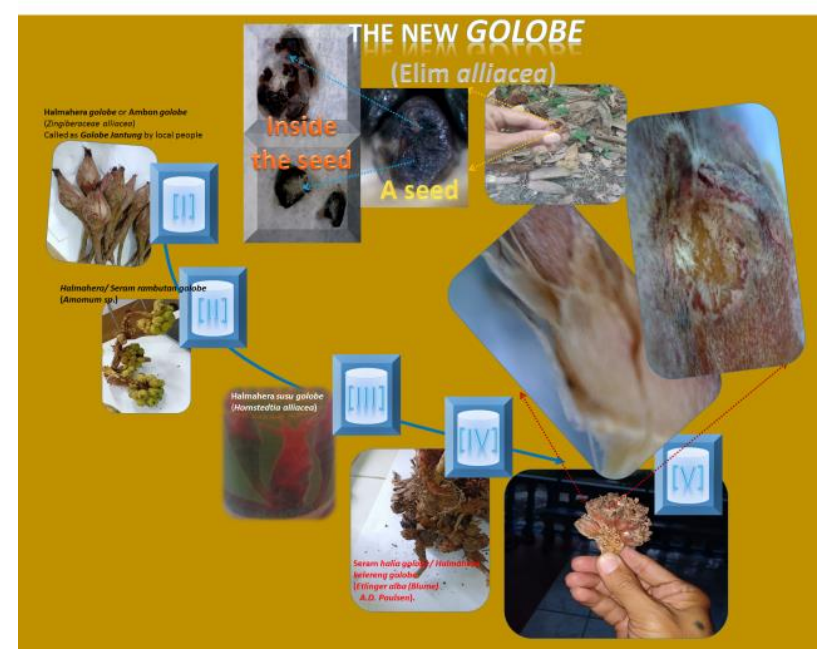

Figure 3. The inner beauty of Elim alliacea with a bit bitter taste inside its seed of the fruit. 
Figure 4 shows briefly how the herbal medicine was prepared starting from breaking the hard outer skin of Elim alliacea with a mechanical tool as depicted in the figure. This type of hard skin is absolutely different from another 4 types golobe with soft outer various skins as shown in Fig. 3. The inside of fruit contains many small seeds with the total seeds weight of 1 fruit is about 0.72 to 0.74 gram. The taste of this new fruit was also a bit bitter differed from the former 4 types with sweet and sour tastes. In order to make the medicine, these all seeds were grilled and dried. To test the herbal medicine functions as ever conducted before using the former four types as chemotherapy herbal medicine [15], and HIV virus killer [13], one used $0.48 \mathrm{~g}$ of toxic (betadine) diluted in $40 \mathrm{~mL}$ of pure drinking water as depicted inside Fig. 4, and then the same amount of medicine was inserted to the liquid. The result of the medicine was so instant to penetrate the toxic as the color of toxic changed from brown to be white. Such indication implies that the medicine has certain active substances to absorb the toxic. Further deep study is needed to find out its originality.

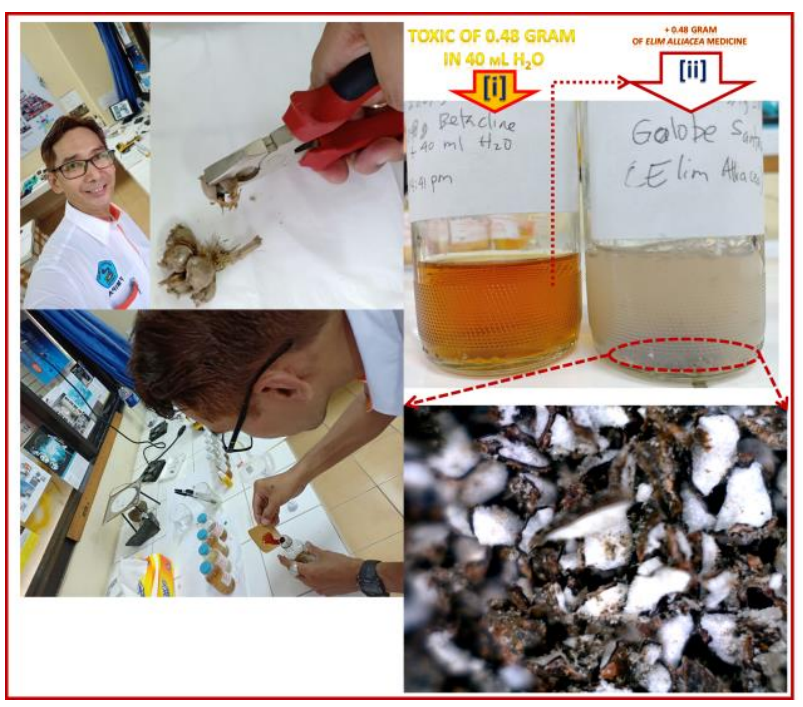

Figure 4. The amazing healing system of herbal Elim alliacea medicine in handling toxic with the concentration of toxic (betadine) is $0.48 \mathrm{~g}$ the same as the content of the medicine in solvent of drinking water $\left(\mathrm{H}_{2} \mathrm{O}\right)$.
In summary, we have invented a new type of zingiberaceae/ golobe fruit named as Elim alliacea. The physical tree and the outer skin of the fruit are in contrast to the former 4 types of golobe. The Elim alliacea is much taller than the former 4 types of golobe. Moreover, the outer skin was much harder, and the seeds taste was a bit bitter. The herbal medicine based on Elim alliacea could handle toxic instantly. In addition, we suggest amazing multitasking healing system with further works for a detail target of healing system.

\section{Acknowledgement}

Part of this work was funded by a partial support from world class research (WCR) grant provided by Indonesia Ministry of Higher Education (Ristek-Dikti) from this year of 2019 to 2021 about "Nanotechnology Strorage Mobile NanoBattery (SMN-B) for Future Energy Sources." This NanoBattery system was based on a deep learning from natural products.

\section{References}

[1]. Holy Bible, for example in The book of Genesis, Chapter 1 to 3, and The book of Ezekiel, Chapter 47:12.

[2]. G.G. Tapadiya, M.A. Kale, and S.S. Saboo, Impact of Nanotechnology on Global Trade of Herbal Drugs: An Overview, International Journal of Green Pharmacy 11(3), S171 (2017).

[3]. E. Stokstad, The New potato, Science 363 (6427), pp. 574-577 (2019).

[4]. H.I. Elim, Nanomedicine with Its Multitasking Applications: A View for Better Health, International Journal of Health Medicine and Current Research (IJHMCR, http://www.ijhmcr.com) 2 (02), 353-357 (2017).

[5]. H.I. Elim, Physics of Multitasking Nanomedicine, IJHMCR 2 (03), 509-519 (2017).

[6]. H.I. Elim, METODE FISIKA EKSPERIMEN: PELENGKAP TEORI FISIKA: "To be Perfect like The 1 Who Created Our Incredible Universe". ISBN: 978-602-5943-05-8 (in Indonesia with 155 pages).

[7]. H.I. Elim, THE FIRST 1000 ATOMS IN HEALING PROCESS: FROM NANOTECHNOLOGY TO 
NANOMEDICINE, IJHMCR 3 (04), 1044-1046 (2018). DOI: 10.22301/IJHMCR.2528-3189.1044

[8]. H.I. Elim, Nonlinear Optics and The Frontier of Nanoscience and Nanotechnology, Pattimura University Press, 2018. ISBN: 987-602-61906-9-7 (in English with 144 pages).

[9]. H.I. Elim, Multitasking Herbal Nanomedicine: A Frontier Report, Nanoscale Reports Vol. 2, Issue 1, pp. 22-30 (2019).

[10]. B. Alberts, Science Breakthroughs (Editor-in-Chief's Editorial paper), Science 334 (6063), p. 1604 (2011).

[11]. A. L.Mapanawang, F. Sambode, M. Killing, S. Mapanawang, B. Dijnimangake, A. Maengkom, P. Pranata, F. Mapanawang, H. Maengkom, H. Averous, A. Musa, W. Murary, G. Mapanawang, Ismail, T. Sitanala, F. Syahputra, L. Lamidja, and J. Djafar, IDENTIFICATION OF ANTIOXIDANT ACTIVITY OF GOLOBE HALMAHERA (HORNSTEDTIA SP, ZINGIBERACEAE) FRUIT EXTRACT, International Journal of Pharmacy Review \& Research (www.ijprr.com), 6 (1), pp.31-34 (2016).

[12]. H.I. Elim, and A.L. Mapanawang, THE ATTRACTIVE DIFFERENCES OF TWO TYPES OF HERBAL MEDICINE FROM ZINGIBERACEAE FRUIT (GOLOBE HALMAHERA), IJHMCR 3 (01), 799-806 (2018).

[13]. A.L. Mapanawang, and H.I. Elim, Chemical Bonding Character of Love Herbal Medicine: A Prominent Medicine Candidate for Preventing HIV virus, Nanotechnology and Applications 1 (1), (2018). DOI: 10.33425/2639-9466.1003.
[14]. H.I. Elim, and A.L. Mapanawang, Electronics Physical System of Large Antioxidant Structure in Herbal Medicine based Zingiberaceae Fruit: Understanding and Application, Nanotechnology and Applications 1 (1), (2018). DOI: 10.33425/2639-9466.1004.

[15]. A.L. Mapanawang, and H.I. Elim, Unique Chemical Bonding Behavior of Love Herbal Medicine and Its Conjunction with Chemotherapy Drug, Journal of Nanomedicine and Nanotechnology 9 (3), 1000503 (2018).

[16]. H.I. Elim, Scientific Breakthrough Based on Natural Creation: "1 Diamond with 7 Eyes", COJ Reviews and Research 1 (1), 1-4 (2018).

\footnotetext{
*Corresponding Author Brief CV

Dr. H.I. Elim is a 2017 scientist Indonesia from Pattimura university. He has focused on his works in physics of nanoscience, nanotechnology and nanomedicine since 2001 up to present. Dr. Elim already published over 49 papers with $h$ index of 24 and citation more than 2200 . Since 2015, he had started the first nanotechnology research center and innovative creation (PPNRI) in the eastern part of Indonesia located at Pattimura university. During the last 5 years, he published about 16 international papers from the institution with several invited talks in international conferences as well as few important invited quest lectures in national universities such as Universitas Negeri Manado, Universitas Sam Ratulangi and Universitas Indonesia. In addition, Dr. Elim has educated more than 50 physics research students.
} 